\section{Plasmacytoma-Like Post-Transplantation} Lymphoproliferative Disease Occurring in a Cardiac Allograft: A Case Report and Review of the Literature

\section{Case Report}

A 33-year-old woman with a history of an orthotopic heart transplantation in 2006 for a left anterior descending artery dissection presented 5 years post-transplantation with intermittent palpitations and light headedness for 2 months. The patient had multiple episodes of acute and chronic rejection since her transplantation, and her immunosuppression consisted of prednisone $5 \mathrm{mg}$ per day, mycophenolate mofetil, tacrolimus, and rapamune at the time of presentation. Telemetry monitoring revealed a new onset of sinus pauses. An echocardiogram showed normal biventricular function with left ventricular hypertrophy and biatrial enlargement. Myocardial magnetic resonance imaging of the heart demonstrated patchy areas of delayed contrast enhancement that mostly involved the left ventricular infe- rior and lateral wall (Fig 1A, arrow), foci within the inferior septum (Fig 1B, arrow), and the right ventricular free wall and apex, which indicated a pattern not typical of ischemic disease and most compatible with an infiltrative process. An endomyocardial biopsy revealed sheets of plasma cells (Figs 2A and 2B; hematoxylin and eosin stain; original magnifications: A, $\times 20 ; \mathrm{B}, \times 100)$ that were CD138+ $($ Fig $2 \mathrm{C}$; immunohistochemical stain for CD138; original magnification $\times 40$ ) and light chain restricted (Fig 2D; in situ hybridization stain for kappa light chains; original magnification $\times 20$ ), with only occasional lightchain positivity (Fig 2E; in situ hybridization stain for lambda light chains; original magnification $\times 20$ ). Epstein-Barr virus $(\mathrm{EBV})$-encoded RNA in situ hybridization stain was negative (Fig 2F; original magnification $\times 40$ ). Diffuse lymphocytic infiltrates of the myocardium were found in the background, which were consistent with grade $1 \mathrm{R}$ cellular rejection according to the International Society for Heart and Lung Transplantation criteria. ${ }^{1}$ This presentation was consistent with plasmacytoma-like monomorphic B-cell posttransplantation lymphoproliferative disease (PTLD) occurring in the setting of graft rejection.
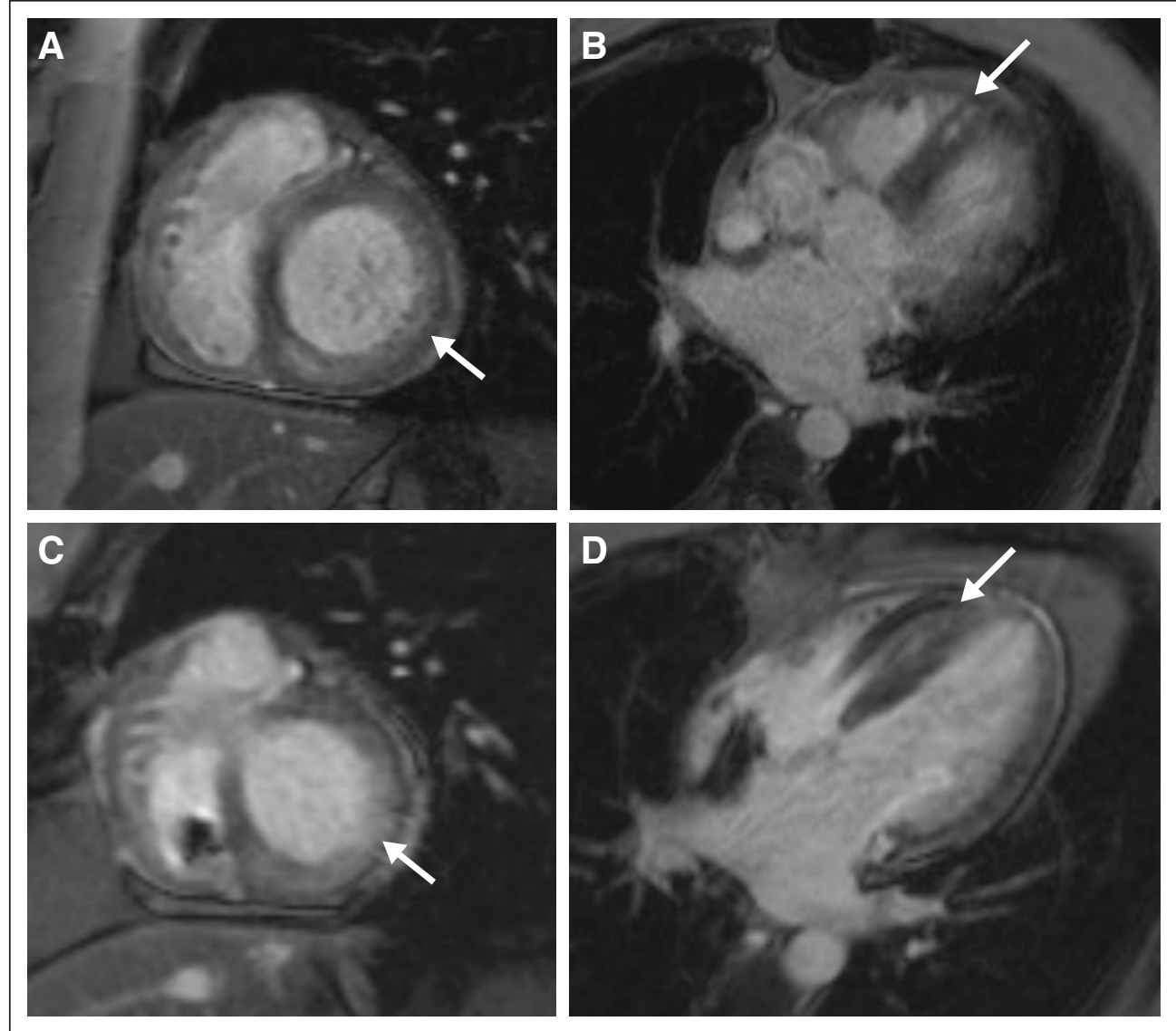

Fig 1. 

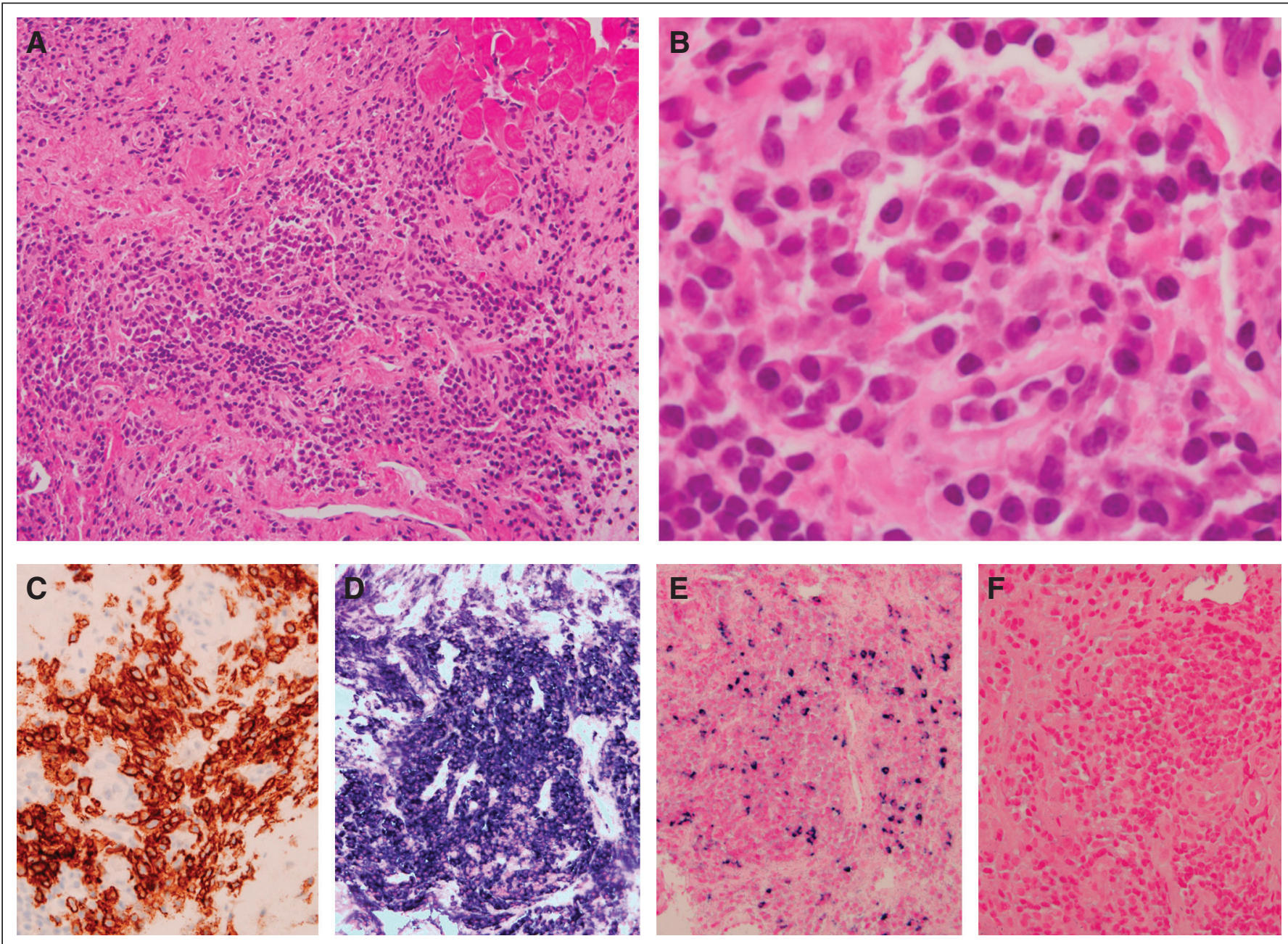

Fig 2.

An additional staging workup was performed. Serum protein electrophoresis demonstrated a possible abnormal $\lambda$-restricted peak in the $\gamma$ region of $0.2 \mathrm{~g} / \mathrm{dL}$, which was inconsistent with the endomyocardial biopsy that demonstrated a $\kappa$ restriction. Subsequent testing before and after therapy did not confirm the presence of an abnormal restricted peak. $\beta-2$ microglobulin was slightly increased at $2.8 \mathrm{mg} / \mathrm{L}$. Serum-free $\kappa$ and $\lambda$ light chains were within normal ranges at $1.49 \mathrm{mg} / \mathrm{dL}$ (normal range, 0.33 to $1.94 \mathrm{mg} / \mathrm{dL}$ ) and $0.85 \mathrm{mg} / \mathrm{dL}$ (normal range, 0.57 to $2.63 \mathrm{mg} / \mathrm{dL}$ ), respectively; however, the $\kappa: \lambda$ ratio was slightly increased to 1.75 (normal range, 0.26 to 1.65 ). Urine electrophoresis and immunofixation were unremarkable. A wholebody $\left[{ }^{18} \mathrm{~F}\right]$ fluorodeoxyglucose positron emission tomography scan revealed increased right myocardial $\left[{ }^{18} \mathrm{~F}\right]$ fluorodeoxyglucose uptake, likely as a result of PTLD (Fig 3, arrow). A bone marrow biopsy, computed tomography scans of the chest, abdomen, and pelvis, and skeletal surveys did not reveal any evidence of systemic involvement of the PTLD.

The decision was made to reduce immunosuppression despite evidence of low-grade chronic rejection. Mycophenolate mofetil was discontinued, but the patient continued to receive tacrolimus, rapamune, and low-dose prednisone. Repeat endomyocardial biopsies after 1 and 2 months showed grade $2 \mathrm{R}$ acute cellular rejection and persistent, although decreased, involvement by plasmacytoma-like PTLD. With evidence of ongoing acute rejection, it was felt that the immunosuppression of the patient could not be safely reduced further, and she was given subcutaneous bortezomib at a dose of 1.3 $\mathrm{mg} / \mathrm{m}^{2}$ per day on days $1,4,8$, and 11 of a 28 -day cycle. After three cycles of bortezomib, a repeat magnetic resonance imaging of the heart showed a modest interval decrease in the left-ventricle contrast enhancement (Figs 1C and 1D, arrows). After four cycles of bortezomib, the chronic palpitations of the patient improved subjectively. Her treatment is ongoing.

\section{Discussion}

Post-transplantation lymphoproliferative disorders (PTLDs) consist of a variety of lymphoid or plasmacytic proliferations that develop as a consequence of immunosuppression in the setting of solid organ or bone marrow transplantation. PTLDs remain rare but are one of the most morbid complications after solid organ transplantation. The frequency of PTLDs varies from less than $1 \%$ in patients with renal transplantation to more than $5 \%$ in heart or lung transplantation recipients. ${ }^{2}$ Monomorphic PTLDs most commonly resemble diffuse large-B-cell lymphoma or Burkitt's lymphoma, whereas plasmacytoma-like PTLDs are much less common and account for 


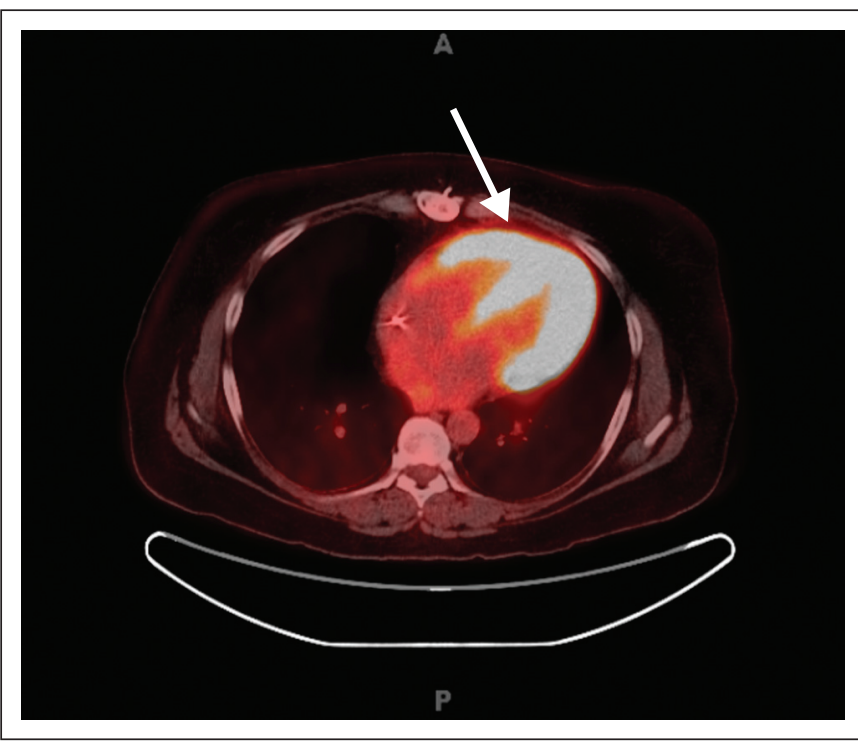

Fig 3.

less than $4 \%$ of PTLDs. ${ }^{3}$ In addition, PTLDs are usually found in the lymph nodes, gastrointestinal tract, kidney, and liver and much less commonly in an allograft. Allograft involvement is often found in early lesions in patients who are EBV positive. Cardiac allograft involvement, as found in our patient, is exceedingly rare. According to the WHO classification, PTLDs can be divided into the following three main categories: early lesions, polymorphic, and monomorphic PTLDs. ${ }^{2}$ The first category is characterized by lymphoid proliferations with preserved architecture of the involved tissues with plasmacytic hyperplasia and infectious mononucleosis-like features. In the latter two categories, architecture effacement of involved tissues is seen. Monomorphic PTLDs are often clinically indistinguishable with the corresponding lymphomas or plasma-cell dyscrasias in immunocompetent hosts.

Because of their rarity, there is a paucity of literature on plasmacytoma-like PTLDs. All articles have been case reports or small case series. ${ }^{4-27}$ A summary of all published cases found in PubMed up to November 2011, and modified from the table by Richendollar et al, ${ }^{4}$ is presented in Table 1. Thirty-seven cases were included. All cases occurred after a solid organ transplantation. The majority of cases involved skin and lymphoid tissues, and only three cases involved an allograft (one kidney and two livers). The median age of patients was 56 years old; $22 \%$ of patients (eight of 37 ) were below the age of 40 years at diagnosis, whereas $30 \%$ of patients ( 11 of 37 ) were more than 60 years of age. Eighty percent of patients were men. Fiftythree percent of cases (17 of 32) were EBV positive, and $49 \%$ of cases (17 of 35) were $\lambda$ restricted. Unlike lymphoma-like PTLDs, which usually present within 1 to 2 years after transplantation, plasmacytoma-like PTLDs typically demonstrated a delayed onset. Only six patients developed disease within 1 year, and the majority of other patients developed disease after more than 3 years, with the longest instance being almost 26 years post-transplantation. ${ }^{10}$ No apparent correlations were identified among the type of protein restriction ( $\kappa$ or $\lambda$ ), the sites of involvement, or EBV positivity.

Among the 33 patients with available treatment records, 31 patients had a reduction of immunosuppression and/or radiation ther- apy as initial treatment, which indicated that they remained the mainstay of treatment for plasmacytoma-like PTLDs. Chemotherapy was added in 15 cases for refractory or progressive diseases. One patient achieved complete remission with autologous stem-cell transplantation. ${ }^{18}$ Allogeneic stem-cell transplantation was done in another patient without significant benefits. ${ }^{21}$ Treatment responses were unclear in six patients. Among the remaining 31 patients, 17 patients (55\%) were free of disease at the last follow-ups, although 28 patients $(90 \%)$ had at least partial responses at some point. These results were consistent with the favorable outcome demonstrated by a recently published prospective registry series. ${ }^{10}$ However, publication biases may have contributed to these positive results. In addition, the follow-up in most cases was relatively short (within 2 years).

To our knowledge, this is the first report of plasmacytoma-like PTLD that occurred within a cardiac allograft. PTLD occurred five years after the transplantation, which was consistent with the delayed onset seen in the literature with this disease. The EBV-encoded RNA in situ hybridization of the patient was negative. The proportion of EBV-negative PTLDs is on the increase in the past decade (up to 50\% to $60 \%$ in some series), although the proportion varies widely among studies. $^{2,28}$ This type of PTLD usually occurs later after transplantation, with a median of 50 months post-transplantation compared with 10 months in patients with EBV-positive PTLD. ${ }^{28}$ EBV-negative PTLDs are typically monomorphic and carry a poor prognosis. ${ }^{28}$ Because of the location of the disease of our patient (endomyocardium), radiation therapy was contraindicated. Although immunosuppression was tapered in this patient, the development of acute rejection precluded the additional reduction needed to treat her PTLD. Chemotherapy regimens, such as vincristine, doxorubicin, and dexamethasone, melphalan, and cyclophosphamide plus prednisone, have been reported in the literature as treatments for plasmacytoma-like PTLDs with various degree of success. ${ }^{4,7,10,12,22}$ In recent years, bortezomib, which is a proteasome inhibitor, has become a mainstay for plasma-cell dyscrasia. From our experiences in this case, we feel that bortezomib represents a feasible treatment option with low toxicity for plasmacytoma-like PTLDs.

\section{Tzu-Fei Wang, Jonathan L. Klein, Pamela K. Woodard, Anjum Hassan, Susan M. Joseph, Gregory A. Ewald, and Geoffrey L. Uy \\ Washington University School of Medicine, St Louis, MO}

\section{AUTHORS' DISCLOSURES OF POTENTIAL CONFLICTS OF INTEREST}

The author(s) indicated no potential conflicts of interest.

\section{REFERENCES}

1. Stewart S, Winters GL, Fishbein MC, et al: Revision of the 1990 working formulation for the standardization of nomenclature in the diagnosis of heart rejection. J Heart Lung Transplant 24:1710-1720, 2005

2. Swerdlow SH, Webber SA, Chadburn A, et al: Post-transplant lymphoproliferative disorders, in Swerdlow SH (ed): WHO Classification of Tumours of Haematopoietic and Lymphoid Tissues. Lyon, France, International Agency for Research on Cancer, 2008, pp 343-349

3. Armitage JM, Kormos RL, Stuart RS, et al: Posttransplant lymphoproliferative disease in thoracic organ transplant patients: Ten years of cyclosporinebased immunosuppression. J Heart Lung Transplant 10:877-887, 1991

4. Richendollar BG, Hsi ED, Cook JR: Extramedullary plasmacytoma-like posttransplantation lymphoproliferative disorders. Am J Clin Pathol 132:581-588, 2009

5. Leigh BR, Larkin EC, Doggett RL: Solitary extramedullary plasmacytoma five years after successful cardiac transplantation: Case report and review of the literature. Am J Clin Oncol 20:467-470, 1997 


\begin{tabular}{|c|c|c|c|c|c|c|c|c|c|}
\hline $\begin{array}{c}\text { Case and } \\
\text { Reference } \\
\text { No. }\end{array}$ & $\begin{array}{c}\text { Age } \\
\text { (years) }\end{array}$ & Sex & $\begin{array}{c}\text { Transplantation } \\
\text { Type }\end{array}$ & $\begin{array}{l}\text { Time Since } \\
\text { Transplantation }\end{array}$ & Site & $\begin{array}{l}\text { Monoclonal } \\
\text { Light-Chain } \\
\quad \text { lg }\end{array}$ & EBER & Treatment & Responses \\
\hline $1^{4}$ & 17 & M & Heart & 9.5 years & Adenoids & $\lambda$ & Neg & $\mathrm{ROI}$ & CR, NED at 2.3 years \\
\hline $2^{5}$ & 56 & M & Heart & 5.5 years & Skin & $\kappa$ & NA & $\mathrm{XRT}$ & $\begin{array}{l}\text { CR at } 1 \text { month, progression } \\
\text { to } \mathrm{MM} \text { at } 2 \text { months, } \\
\text { DOD at } 6 \text { months }\end{array}$ \\
\hline $3^{6}$ & 61 & $\mathrm{~F}$ & Heart & 9 years & Skin & $\lambda$ & NA & NA & NA \\
\hline $4^{7}$ & 63 & M & Heart & 8 years & Skin & $\kappa$ & Neg & ROI, VAD, XRT & $\mathrm{CR}$ at 5 months \\
\hline $5^{8}$ & 57 & M & Heart & 10 years & Skin & $\lambda$ & Pos & XRT, excision & $\begin{array}{l}\text { Multiple relapses, died as } \\
\text { result of heart failure }\end{array}$ \\
\hline $6^{8}$ & 54 & M & Heart & 8 years & Skin & $\lambda$ & Pos & $\mathrm{ROI}$ & $\mathrm{CR}$ \\
\hline $7^{9}$ & 56 & $\mathrm{~F}$ & Heart & 3 years & Peritoneum & $\lambda$ & NA & NA & NA \\
\hline $8^{10}$ & 53 & M & Heart & $\begin{array}{l}5 \text { years, } 10 \\
\text { months }\end{array}$ & Retroperitoneum & $\kappa$ & Neg & ROI, XRT & NA \\
\hline $9^{11}$ & 58 & M & Lung & 9 years & Skin, mouth & $\lambda$ & Pos & XRT & PR, DOD at 6 months \\
\hline $10^{10}$ & 51 & $\mathrm{~F}$ & Lung & $\begin{array}{l}13 \text { years, } 10 \\
\text { months }\end{array}$ & Nasal cavity/sinuses & $\kappa$ & Pos & XRT & SD at $>9$ months \\
\hline $11^{12}$ & 55 & $\mathrm{~F}$ & Liver & 0.5 years & Pleura, kidney & $\lambda$ & $\mathrm{Neg}$ & ROI, Mel, P & $\mathrm{PR}, \mathrm{DOD}$ \\
\hline $12^{4}$ & 37 & M & Liver & $\begin{array}{l}4 \text { years, } 11 \\
\text { months }\end{array}$ & Lymph node & $\lambda$ & Neg & $\mathrm{ROI}$ & $\begin{array}{l}\mathrm{CR} \text {, relapse, } \mathrm{DOD} \text { at } 8 \\
\text { years }\end{array}$ \\
\hline $13^{4}$ & 48 & M & Liver & $\begin{array}{l}6 \text { years, } 5 \\
\text { months }\end{array}$ & Lymph node & $\kappa$ & Pos & ROI, R, T & $\begin{array}{l}\mathrm{CR} \text {, relapse at } 5 \text { years, } \mathrm{CR} \\
\quad \text { again }\end{array}$ \\
\hline $14^{8}$ & 58 & M & Liver & 8 years & Skin & $\lambda$ & Pos & $\mathrm{ROI}$ & $\mathrm{CR}, \mathrm{NED}$ at 2 years \\
\hline $15^{13}$ & 66 & M & Liver & 2 months & Liver allograft & $\lambda$ & Pos & ROI & CR at 4 months \\
\hline $16^{10}$ & 66 & M & Liver & 3.5 months & Liver allograft & $\kappa$ & Neg & $\begin{array}{l}\mathrm{ROI}, \mathrm{D}, \mathrm{CHOP}, \\
\quad \text { retransplantation }\end{array}$ & $\mathrm{CR}$ \\
\hline $17^{14}$ & 52 & M & Liver/kidney & 1 year, 5 months & Abdomen and bladder & $\kappa$ & Pos & ROI, XRT & CR, NED at 24 months \\
\hline $18^{15}$ & 33 & M & Kidney & 9 years & Lymph node & $\kappa$ & Neg & NA & NA \\
\hline $19^{16}$ & 59 & NA & Kidney & 7 years & Kidney allograft & $\kappa$ & Neg & ROI, resection & CR, NED at 12 months \\
\hline $20^{17}$ & 63 & M & Kidney & 6 years & Tonsil & $\lambda$ & Neg & NA & NA \\
\hline $21^{18}$ & 52 & M & Kidney & 11 months & Left flank & $\kappa$ & NA & $\begin{array}{l}\text { ROI, XRT, R, ESHAP, } \\
\text { mini-BEAM, auto- } \\
\text { HSCT }\end{array}$ & $\begin{array}{l}\text { Multiple relapses, CR after } \\
\text { HSCT, NED at } 31 \\
\text { months }\end{array}$ \\
\hline $22^{19}$ & 10 & M & Kidney & 5 years & Left groin & $\lambda$ & Pos & $\mathrm{ROI}$ & $\mathrm{CR}, \mathrm{NED}$ at 20 months \\
\hline $23^{20}$ & 59 & M & Kidney & 12 years & $\begin{array}{l}\text { Thigh, scalp, } \\
\text { abdomen }\end{array}$ & $\kappa$ & Pos & ROI, C, P, XRT & $\begin{array}{l}\mathrm{CR} \text {, died at } 2 \text { months as } \\
\text { result of infection }\end{array}$ \\
\hline $24^{21}$ & 65 & M & Kidney & 13 years & Nasal tissue & $\kappa$ & Pos & $\begin{array}{l}\text { ROI, XRT, CVP, allo- } \\
\text { HSCT, MTX }\end{array}$ & $\begin{array}{l}\mathrm{PR} \text {, progression, } \mathrm{DOD} \text { at } 8 \\
\text { months }\end{array}$ \\
\hline $25^{22}$ & 36 & F & Kidney & 8 years & $\begin{array}{l}\text { Bladder, small bowel, } \\
\text { peritoneum }\end{array}$ & $\lambda$ & Neg & ROI, VAD & $\begin{array}{l}\text { CR, relapse at } 10 \text { months, } \\
\text { DOD at } 1 \text { year }\end{array}$ \\
\hline $26^{4}$ & 52 & M & Kidney & $\begin{array}{r}7 \text { years, } 2 \\
\text { months }\end{array}$ & Skin & $\lambda$ & Pos & $\mathrm{ROI} \mathrm{R}, \mathrm{C}, \mathrm{P}$ & $\mathrm{CR}$, relapse at 3.3 years \\
\hline $27^{23}$ & 63 & M & Kidney & 16.5 years & Nose & $\lambda$ & Pos & XRT, C, P, resection & PR at 10 months \\
\hline $28^{24}$ & 64 & M & Kidney & 7 years & Skin & $\kappa$ & Neg & XRT, chlorambucil ROI & $\begin{array}{l}\text { CR, NED at } 8 \text { years, died } \\
\text { as result of other reason }\end{array}$ \\
\hline $29^{25}$ & 66 & M & Kidney & 4 years & Skin & $\kappa$ & Neg & $\mathrm{ROI}, \mathrm{XRT}$ & $\mathrm{CR}$, NED at 2 years \\
\hline $30^{26}$ & 41 & M & Kidney & 0.5 years & Ileum & NA & NA & None & $\begin{array}{l}\text { Died of sepsis and liver } \\
\text { failure }\end{array}$ \\
\hline $31^{27}$ & 55 & M & Kidney/pancreas & 5 years & Skin & $\kappa$ & Pos & XRT & CR, NED at 1 year \\
\hline $32^{8}$ & 25 & $\mathrm{~F}$ & Kidney & 8 years & Skin & NA & Pos & $\mathrm{R}$ & $\mathrm{CR}$ \\
\hline $33^{10}$ & 56 & M & Kidney & $\begin{array}{l}10 \text { years, } 9 \\
\text { months }\end{array}$ & Stomach & $\lambda$ & Neg & $\mathrm{ROI}$ & $\begin{array}{l}\text { Unclear, died as result of } \\
\text { SCC at } 1.5 \text { years }\end{array}$ \\
\hline $34^{10}$ & 72 & M & Kidney & $\begin{array}{l}25 \text { years, } 10 \\
\text { months }\end{array}$ & Lymph nodes & $\kappa$ & Neg & ROI & PR at 4 months \\
\hline $35^{10}$ & 39 & $\mathrm{~F}$ & Kidney & $\begin{array}{l}18 \text { years, } 1 \\
\text { month }\end{array}$ & Skin, peritoneum & $\kappa$ & Pos & ROI, PAD, XRT, C & PR at 9 months \\
\hline $36^{10}$ & 68 & M & Kidney/heart & $\begin{array}{l}1 \text { year, } 2 \\
\text { months/4 } \\
\text { years }\end{array}$ & Skin, pleura & $\kappa$ & Pos & ROI, VAD, benda, B & $\begin{array}{l}\text { Progression, DOD at } 14 \\
\text { months }\end{array}$ \\
\hline $37^{10}$ & 24 & M & Small intestine & 3.4 months & Liver, peritoneum & $\lambda$ & Neg & ROI, PAD & $C R$ \\
\hline \multicolumn{10}{|c|}{ 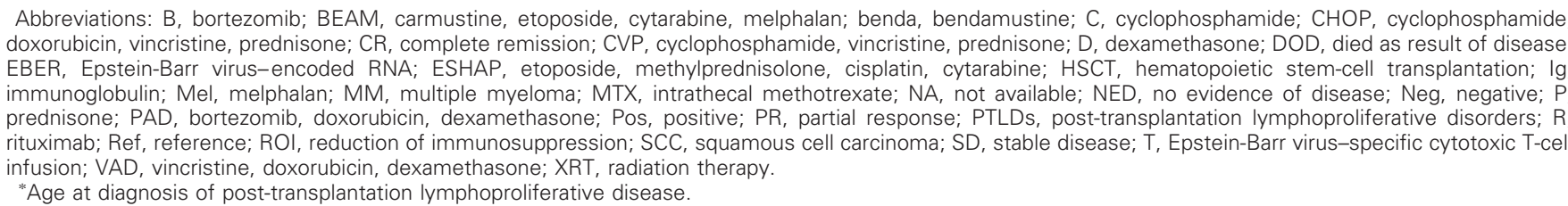 } \\
\hline
\end{tabular}


6. Pacheco TR, Hinther L, Fitzpatrick J: Extramedullary plasmacytoma in cardiac transplant recipients. J Am Acad Dermatol 49:S255-S258, 2003

7. Ibe $W$, Wittlinger $T$, Sebastian $M$, et al: A nonhealing ulcer diagnosed as extramedullary plasmacytoma of the limb eight years after cardiac transplantation. Transplantation 68:901-904, 1999

8. Willoughby $V$, Werlang-Perurena A, Kelly $A$, et al: Primary cutaneous plasmacytoma (posttransplant lymphoproliferative disorder, plasmacytoma-like) in a heart transplant patient. Am J Dermatopathol 28:442-445, 2006

9. Chan BK, Ranheim E, Jeffrey RB Jr: Disseminated peritoneal plasmacytoma following cardiac transplantation. Abdom Imaging 24:508-510, 1999

10. Trappe $R$, Zimmermann $H$, Fink $S$, et al: Plasmacytoma-like post-transplant lymphoproliferative disorder, a rare subtype of monomorphic B-cell posttransplant lymphoproliferation, is associated with a favorable outcome in localized as well as in advanced disease: A prospective analysis of 8 cases. Haematologica 96:1067-1071, 2011

11. McFarlane $R$, Hurst $S$, Sabath $D$, et al: A rare case of plasmacytoma-like post-transplant lymphoproliferative disorder presenting in the skin of a lung transplant patient. J Cutan Pathol 35:599-602, 2008

12. Schemankewitz E, Hammami A, Stahl R, et al: Multiple extramedullary plasmacytomas following orthotopic liver transplantation in a patient on cyclosporine therapy. Transplantation 49:1019-1022, 1990

13. Vishnu $P$, Jiang $L$, Cortese $C$, et al: Plasmacytoma-like posttransplant lymphoproliferative disorder following orthotopic liver transplantation: A case report. Transplant Proc 43:2806-2809, 2011

14. Joseph G, Barker RL, Yuan B, et al: Posttransplantation plasma cell dyscrasias. Cancer 74:1959-1964, 1994

15. Harris NL, Ferry JA, Swerdlow SH: Posttransplant lymphoproliferative disorders: Summary of Society for Hematopathology Workshop. Semin Diagn Pathol 14:8-14, 1997

16. Meehan SM, Domer $P$, Josephson $M$, et al: The clinical and pathologic implications of plasmacytic infiltrates in percutaneous renal allograft biopsies. Hum Pathol 32:205-215, 2001

17. Syed SP, Chase DR, Wang J: Pathologic quiz case: A 63-year-old renal transplant recipient with a sore throat-transplantation lymphoproliferative disorder, plasmacytoma type, with prominent Russell body formation. Arch Pathol Lab Med 128:e76-e78, 2004
18. Komrokji RS, Oliva JL, Zand $M$, et al: Mini-BEAM and autologous hematopoietic stem-cell transplant for treatment of post-transplant lymphoproliferative disorders. Am J Hematol 79:211-215, 2005

19. Rees L, Thomas A, Amlot P: Disappearance of an Epstein-Barr viruspositive post-transplant plasmacytoma with reduction of immunosuppression. Lancet 352:789, 1998

20. Papadaki HA, Stefanaki K, Kanavaros $P$, et al: Epstein-Barr virus-associated high-grade anaplastic plasmacytoma in a renal transplant patient. Leuk Lymphoma 36:411-415, 2000

21. Au WY, Lie AK, Chan EC, et al: Treatment of postrenal transplantation lymphoproliferative disease manifesting as plasmacytoma with nonmyeloablative hematopoietic stem cell transplantation from the same kidney donor. Am J Hematol 74:283-286, 2003

22. Takahashi R, Nakano S, Namura $K$, et al: Plasmacytoma of the urinary bladder in a renal transplant recipient. Int J Hematol 81:255-257, 2005

23. Au WY, Lie AK, Kwong $Y L$, et al: Post-transplantation lymphoproliferative disease in Chinese: The Queen Mary Hospital experience in Hong Kong. Leuk Lymphoma 43:1403-1407, 2002

24. Salama S, Todd S, Cina DP, et al: Cutaneous presentation of post-renal transplant lymphoproliferative disorder: A series of four cases. J Cutan Pathol 37:641-653, 2010

25. Tessari G, Fabbian F, Colato C, et al: Primary cutaneous plasmacytoma after rejection of a transplanted kidney: Case report and review of the literature. Int J Hematol 80:361-364, 2004

26. Kuster G, Woods JE, Anderson CF, et al: Plasma cell lymphoma after renal transplantation. Am J Surg 123:585-587, 1972

27. Wang $E$, Stoecker M: Primary cutaneous giant cell plasmacytoma in an organ transplant recipient: A rare presentation of a posttransplant lymphoproliferative disorder. Am J Dermatopathol 32:479-485, 2010

28. Nelson BP, Nalesnik MA, Bahler DW, et al: Epstein-Barr virus-negative post-transplant lymphoproliferative disorders, a distinct entity? Am J Surg Pathol $24: 375-385,2000$

DOI: 10.1200/JCO.2011.39.5855; published online ahead of print at www.jco.org on June 18, 2012 